\title{
Article \\ Comparison of Nature and Synthetic Zeolite for Waste Battery Electrolyte Treatment in Fixed-Bed Adsorption Column
}

\author{
Cong Yang ${ }^{1}$, Yifei Wang ${ }^{2, *(1)}$ and Abdullatif Alfutimie ${ }^{1, *}$ (I) \\ 1 Department of Chemical Engineering and Analytical Science, Faculty of Science and Engineering, \\ The University of Manchester, Manchester M1 3BB, UK; cong.yang@kaust.edu.sa \\ 2 School of Mechanical Engineering and Automation, Harbin Institute of Technology, Shenzhen 518055, China \\ * Correspondence: yifeiwang@hit.edu.cn (Y.W.); abdullatif.alfutimie@manchester.ac.uk (A.A.)
}

check for updates

Citation: Yang, C.; Wang, Y.; Alfutimie, A. Comparison of Nature and Synthetic Zeolite for Waste Battery Electrolyte Treatment in Fixed-Bed Adsorption Column. Energies 2022, 15, 347. https:// doi.org/10.3390/en15010347

Academic Editor: Antonino S. Aricò

Received: 7 November 2021

Accepted: 30 December 2021

Published: 4 January 2022

Publisher's Note: MDPI stays neutral with regard to jurisdictional claims in published maps and institutional affiliations.

Copyright: (C) 2022 by the authors. Licensee MDPI, Basel, Switzerland. This article is an open access article distributed under the terms and conditions of the Creative Commons Attribution (CC BY) license (https:// creativecommons.org/licenses/by/ $4.0 /)$.

\begin{abstract}
To support a sustainable energy development, $\mathrm{CO}_{2}$ reduction for carbon neutralization and water-splitting for hydrogen economy are two feasible technical routes, both of which require a significant input of renewable energies. To efficiently store renewable energies, secondary batteries will be applied in great quantity, so that a considerable amount of energy needs to be invested to eliminate the waste battery electrolyte pollution caused by heavy metals including $\mathrm{Cu}^{2+}, \mathrm{Zn}^{2+}$ and $\mathrm{Pb}^{2+}$. To reduce this energy consumption, the removal behaviors of these ions by using clinoptilolite and zeolite $\mathrm{A}$ under 5, 7 and $10 \mathrm{BV} \mathrm{h}^{-1}$ in a fixed-bed reactor were investigated. The used zeolites were then regenerated by a novel $\mathrm{NH}_{4} \mathrm{Cl}$ solution soaking, coupled with the ultrasonication method. Further characterizations were carried out using scanning electron microscopy, $\mathrm{N}_{2}$ adsorption and desorption test, and wide-angle $\mathrm{X}$-ray diffraction. The adsorption breakthrough curves revealed that the leaching preference of clinoptilolite was $\mathrm{Pb}^{2+}>\mathrm{Cu}^{2+}>\mathrm{Zn}^{2+}$, while the removal sequence for zeolite A was $\mathrm{Zn}^{2+}>\mathrm{Cu}^{2+}>\mathrm{Pb}^{2+}$. The maximum removal percentage of $\mathrm{Zn}^{2+}$ ions for clinoptilolite under $5 \mathrm{BV} \mathrm{h}^{-1}$ was $21.55 \%$, while it was $83.45 \%$ for zeolite A. The leaching ability difference was also discussed combining with the characterization results. The fact that unit cell stayed the same before and after the regeneration treatment approved the efficacy of the regeneration method, which detached most of the ions while doing little change to both morphology and crystallinity of the zeolites. By evaluating the $\mathrm{pH}$ and conductivity changes, the leaching mechanisms by adsorption and ion exchange were further studied.
\end{abstract}

Keywords: fixed-bed column; zeolite; ultrasonication; heavy metal pollution; electrolyte post-treatment

\section{Introduction}

Sustainable energy development is of key importance to the human society, which is especially the case when facing the fossil fuel depletion and the associated global warming issues. To tackle this, great efforts have been made to achieve the carbon neutralization via $\mathrm{CO}_{2}$ reduction to hydrocarbon fuels [1,2]. Alternatively, the hydrogen fuel can be utilized instead in order to totally eliminate the carbon-related issue, which can be produced simply via the water-splitting reaction $[3,4]$. In both ways, a significant amount of energy is required to facilitate the reduction reaction, which has to be coming from various renewable sources such as solar, wind, geothermal and nuclear energy in order to ensure the sustainability. On the other hand, the urge to preserve renewable energies or smoothly couple them with electrical grids requires an effective large-scale energy storage/conversion system, such as batteries and electrolyzers [5]. Batteries are well-known for their high energy efficiency and fast response. Among them, the commercial lithium-ion battery is already very mature in technology, but it still needs further improvement in cost and safety before being applied into the large-scale electrical grid [6]. On the other hand, the rechargeable metal-air battery such as aqueous $\mathrm{Zn}$-air battery is also promising for this mission considering its great cost-efficiency and high safety level [7]. As for electrolyzers, 
they can convert the renewable energy into stable chemicals such as hydrogen gas, which have unique advantages such as negligible self-discharge for long-term storage, low-cost expansion of storage capacity and high energy density. However, the energy efficiency would be lower due to the overpotential loss.

For both batteries and electrolyzers, the electrode is one of the most important components where the electrochemical reaction takes place. Its active surface area, catalytic capability as well as stability, strongly determine the device performance, including power density, energy efficiency and long-term durability. Therefore, significant research has been conducted in exploring new catalysts, catalyst structures and synergistic catalyst combinations, among which the nanostructured electrode is more advanced than conventional monolithic electrodes. On the other hand, the electrolyte is also a prerequisite component which determines the ohmic resistance of the energy device. In general, it contains a large extent of heavy metal ions, which can be a very serious environmental problem considering the ever-increasing demand for energy storage. For instance, as the mostly used heavy metal in daily applications, the high concentration and the high toxicity of the $\mathrm{Cu}^{2+}$ made it urgent to be removed from the water system [8]. Hence, the heavy metal ions in the waste electrolyte need to be removed efficiently, especially for preventing the water pollution resulted from copper, lead, zinc, mercury and manganese ions that have been reported to be increasingly serious in the estuarine floodplain areas [9-11]. Heavy metals including $\mathrm{Pb}^{2+}$ in the sediment can accumulate through the food chain and eventually enter the human body [12], causing damage to the kidney, red blood cells and even DNA damage, eventually leading to conformational changes [13]. These are likely to result in cell-cycle modulation, carcinogenesis, or apoptosis, even at very low concentrations [14,15].

Conventional methods have been used to remove the heavy metal ions from contaminated water, including chemical precipitation [16], electrochemical methods [17], membrane filtration [18] and ion exchange and adsorption. These either require extra electricity input or create additional slurry that demands further treatment. Among these methods, ion exchange and adsorption stand out for its considerable treatment capacity, high removal efficiency, fast response and low energy consumption [14,19]. Moreover, adsorption was considered to be a cost-efficient, easy, flexible and durable process [20]. Due to their abundant resources, renewable property and relatively low cost, zeolites were massively applied in the fields of adsorption, catalysis and ion exchange [21,22]. Zeolites are microporous crystalline aluminosilicates minerals with cage-like structures [23]. The primary building unit of zeolite is based on $\mathrm{TO}_{4}$ tetrahedra, where $\mathrm{T}$ is aluminum or silicon atom, and this structure makes zeolite a suitable material for ion exchange [24]. Some silicon cations are substituted by aluminum cations, yielding a net negative charge in the tectosilicate framework, which gives zeolites a cation exchangeability [25]. Several pieces of literature proved that natural zeolite such as clinoptilolite has been widely applied into the fields of catalytic activities [26] and electrodes [27]. Meanwhile, it was also implemented globally over the years as the most widespread adsorbent to remove heavy metals from wastewater [28-31]. Zeolite A is usually synthesized and used as the carrier for basis of catalyst [32] or selective electrode [33]. Zeolites received the spotlight because of the high catalytic adsorption capacity, controlled acidity, confinement effects and high stability when applied as the catalyst [34].

Many studies have been conducted for leaching heavy metals from contaminated water $[35,36]$ in batch mode. On the other hand, using zeolite for the removal of heavy metals in a fixed-bed column has been attracting attention due to the fact that it can better mimic the real contaminated water treatment process [37-39]. In fixed-bed studies, most of them focus on the selectivity of a certain type of zeolite towards different ions, while little attention is paid to the difference in the leaching performances among different zeolites. Therefore, in this work, we examined clinoptilolite and also zeolite A in the fixed-bed column to compare their leaching performances as well as their corresponding selectivity towards copper, lead and zinc ions. 
The reactivation of used adsorbents is also important in industrial applications. Usually, acid, including nitric acid [40], base or salts were utilized in the regeneration process. However, zeolite is material with aluminol groups at the edge; when zeolite is put under a low $\mathrm{pH}$ value $(\mathrm{pH}<4)$ environment, the gibbsite edge begins to dissolve [41]. Thus, harsh treatment should be avoided. Herein, the combination of soaking and ultrasonic bathing method was proposed as a novel regeneration method. It has been proved that most natural zeolites in their exchanged form are selective for $\mathrm{NH}_{4}{ }^{+}$experimentally [42] and theoretically [43]. Therefore, the combination of $\mathrm{NH}_{4} \mathrm{Cl}$ solution soaking and ultrasonic bathing is likely to enhance regeneration efficiency, which has never been reported before to the best of our knowledge. In general, this work will provide a sustainable treatment method with low energy consumption for waste battery electrolyte by reusing the zeolites, which will contribute to the achievement of clean water and sanitation (goal 6), responsible consumption and reproduction (goal 12), protecting the life on land (goal 15) as well as the life below water (goal 14) of the 17 Sustainable Development Goals (SDGs).

\section{Materials and Methods}

\subsection{Adsorption Experiment Raw Materials}

Lead (II) nitrate $\left(\mathrm{Pb}\left(\mathrm{NO}_{3}\right)_{2}, 99 \%\right)$, copper (II) sulphate pentahydrate $\left(\mathrm{CuSO}_{4} \cdot 5 \mathrm{H}_{2} \mathrm{O}\right)$, zinc chloride $\left(\mathrm{ZnCl}_{2}\right)$ and ammonium chloride $\left(\mathrm{NH}_{4} \mathrm{Cl} \geq 99.5 \%\right)$ were purchased from Sigma-Aldrich with analytical grade. Heavy metal bulk solutions at a concentration of $0.5 \mathrm{~g} \mathrm{~L}^{-1}$ were prepared by dissolving the corresponding salts in the deionized water to mimic the waste battery electrolyte. A $0.01 \mathrm{M}$ nitric acid $\left(\mathrm{HNO}_{3}\right)$ was used to adjust the initial solution $\mathrm{pH}$ to 4 in order to avoid precipitation during all ion exchange experiments. The average size of clinoptilolite was in the range of $9-16 \mathrm{~mm}$, while that of zeolite $\mathrm{A}$ is approximately $5 \mathrm{~mm}$. All zeolites were washed with distilled water five times to remove residue dust on the surface and then dried at $60^{\circ} \mathrm{C}$ for 3 days.

\subsection{Fixed-Bed Adsorption}

The fixed-bed adsorption column was designed as shown in Figure 1. The solution with a specific concentration $(C)$ was injected at a constant volumetric rate $(Q)$ through a peristaltic pump from the bottom of the column, and then the liquid samples were collected from the top of the column. To gain more precise breakthrough curves, samples were taken out every $10 \mathrm{~min}$ at the beginning of the experiment for $1 \mathrm{~h}$. After that, the sampling time was set to be $20 \mathrm{~min}$. The diameter and the length of the column were $4.2 \mathrm{~cm}$ and $21 \mathrm{~cm}$, respectively, and the empty bed volume (BV) was calculated to be $291 \mathrm{~mL}$.
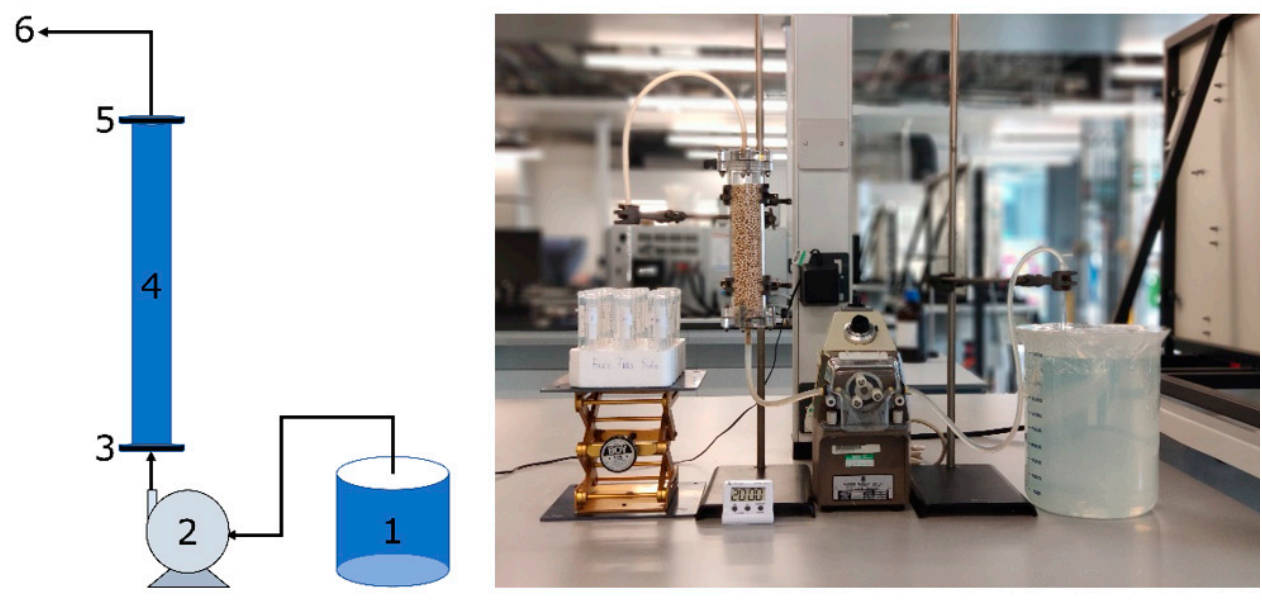

Figure 1. The fixed-bed reactor: (1) represents the heavy metal solution feed tank, then the solution is pumped up through the peristaltic pump (2) to the plexiglass column (4) equipped with a plastic sieve ( 3 and 5 ) at the bottom and the top which is stuffed with zeolites and sent out (6). The optical graph is also presented on the right. 
Fixed bed experiments were carried out in order to compare the leaching performances of zeolite $\mathrm{A}$ and clinoptilolite. Three different heavy metal ions $\left(\mathrm{Cu}^{2+}, \mathrm{Pb}^{2+}\right.$ and $\left.\mathrm{Zn}^{2+}\right)$ and three different volumetric flowrates $\left(5 \mathrm{BV} \mathrm{h}^{-1}=24.25 \mathrm{~mL} \mathrm{~min}^{-1}, 7 \mathrm{BV} \mathrm{h}^{-1}=33.95 \mathrm{~mL} \mathrm{~min}^{-1}\right.$ and $10 \mathrm{BV} \mathrm{h}^{-1}=48.5 \mathrm{~mL} \mathrm{~min}^{-1}$ ) were investigated in this project, and each experiment lasted for $3 \mathrm{~h}$ to ensure that the leaching process reached a stable state.

\subsection{Characterization of the Zeolites Associated with Heavy Metal Adsorption Ions}

The samples were dried under $60^{\circ} \mathrm{C}$ for 3 days and then reserved for the following characterizations: Scanning electron microscopy (FEI Quanta 200 Environmental SEM) was used to study the surface morphology of zeolite samples before and after the adsorption and regeneration. Energy Dispersive X-ray Spectroscopy (EDX) was used to analyze the elemental composition of the adsorbent. The dried samples were further ground into powders and sent for characterizations including $\mathrm{N}_{2}$ adsorption and desorption test, also called Brunauer, Emmett and Teller (BET) test, for the measurement of the pore size and the surface area of the samples. An XRD diffractometer (PANalytical XRD5 (Phillips)) was also used to investigate the crystal phases and the mineral identity of these samples. The $\mathrm{X}$-ray source was generated by copper $\mathrm{K} \alpha$ radiation, the scanning range started from $15^{\circ}$ to $100^{\circ}$ at a rate of $5^{\circ} / \mathrm{min}, 0.02^{\circ} /$ step.

The heavy metal concentrations in the liquid samples were measured by inductively coupled plasma optical emission spectrometry (ICP-OES). The exit relative metal concentration $\left(C_{t} / C_{0}\right)$ was defined by the following equation:

$$
C_{t} / C_{0}=\frac{\left(C_{0}-C_{R}\right)}{C_{0}} \times 100 \%
$$

where $C_{0}$ is the initial solution concentration, $C_{t}$ is the solution concentration at time $t$, $C_{R}$ represents the removed solution concentration. Therefore, the smaller the $C_{t} / C_{0}$ value, the more the corresponding contaminants are removed. By plotting $C_{t} / C_{0}$ versus bed volume, the breakthrough curves were then obtained. Meanwhile, the $\mathrm{pH}$ and the conductivity of the samples were measured simultaneously by the $\mathrm{pH}$ meter (Eutech PC 2700, Thermo Scientific, Waltham, MA, USA).

\subsection{Regeneration Experiments}

The used zeolites were washed 5 times with distilled water and placed in an oven at $60{ }^{\circ} \mathrm{C}$ for 3 days to be fully dried. Then, they were weighed and poured into a $500 \mathrm{~mL}$ beaker before adding $300 \mathrm{~mL}$ regeneration solution $\left(\mathrm{NH}_{4} \mathrm{Cl}\right.$ at the concentration of $\left.1 \mathrm{~g} \mathrm{~L}^{-1}\right)$, and the mixture was ultrasonicated at room temperature for $2 \mathrm{~h}$. The regenerated zeolite was also washed 5 times with distilled water and placed in an oven at $60^{\circ} \mathrm{C}$ for 3 days to be fully dried.

\section{Results}

\subsection{Heavy Metal Ions Leaching Experiments}

The adsorption behavior of both zeolites toward $0.5 \mathrm{~g} \mathrm{~L}^{-1} \mathrm{Cu}^{2+}, \mathrm{Zn}^{2+}$ and $\mathrm{Pb}^{2+}$ was studied under $5 \mathrm{BV} \mathrm{h}^{-1}, 7 \mathrm{BV} \mathrm{h}^{-1}$ and $10 \mathrm{BV} \mathrm{h}^{-1}$ in a fixed-bed adsorption column. As shown in Figure 2, the leaching speed of $\mathrm{Cu}^{2+}, \mathrm{Zn}^{2+}$ and $\mathrm{Pb}^{2+}$ ions via both zeolites gradually decreased over time. The lower flow rate of the feed solution in the column provided a longer contact time for the adsorption process between the heavy metal ions and the adsorbents. Therefore, $5 \mathrm{BV} \mathrm{h}^{-1}$ flow rate provided the longest contact time, hence enhancing the leaching performance. 

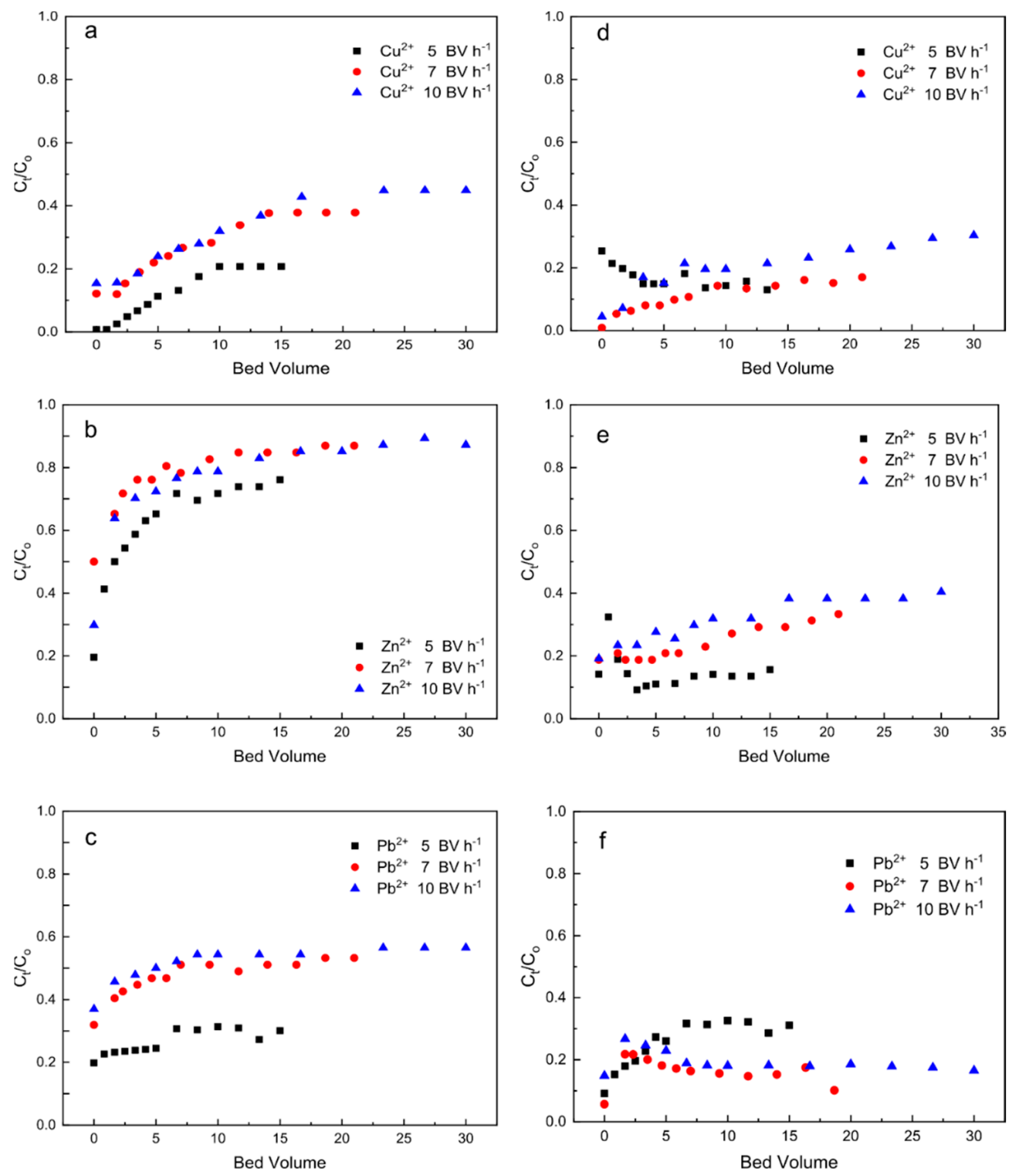

Figure 2. Breakthrough curves of clinoptilolite leaching $\mathrm{Cu}^{2+}(\mathbf{a}) ; \mathrm{Zn}^{2+}(\mathbf{b}) ; \mathrm{Pb}^{2+}(\mathbf{c})$ and zeolite $\mathrm{A}$ leaching $\mathrm{Cu}^{2+}$ (d); $\mathrm{Zn}^{2+}$ (e); $\mathrm{Pb}^{2+}$ (f) under $5 \mathrm{BV} \mathrm{h}^{-1}, 7 \mathrm{BV} \mathrm{h}^{-1}$ and $10 \mathrm{BV} \mathrm{h}^{-1}$.

Overall, $\mathrm{Zn}^{2+}$ has more affinity to Zeolite $\mathrm{A}$, while $\mathrm{Pb}^{2+}$ was more prone to be adsorbed by clinoptilolite. The corresponding $\mathrm{pH}$ and conductivity evaluations were also illustrated in Figures 3 and 4. After the $\mathrm{Zn}^{2+}$ solutions passed through the fixed-bed adsorption column with clinoptilolite, the $\mathrm{pH}$ increased from 4 to 6.5 (on average) and there were negligible changes during the whole experiment time. This indicates that the amount of $\mathrm{H}^{+}$ion in the solution decreased due to the $\mathrm{H}^{+} / \mathrm{Na}^{+}$exchange according to Kurtoğlu and Atun [44]. In the case of zeolite $\mathrm{A}$, the $\mathrm{pH}$ increased to 8 (on average) and then decreased to 6.5 (on average), which could be attributed to the increased concentration of heavy metal ions in the effluent solution. The ions bounded with the $\mathrm{H}_{2} \mathrm{O}$ molecular, leading to the hydrolysis effect and resulting in a decrease of $\mathrm{pH}$ value [45]. 

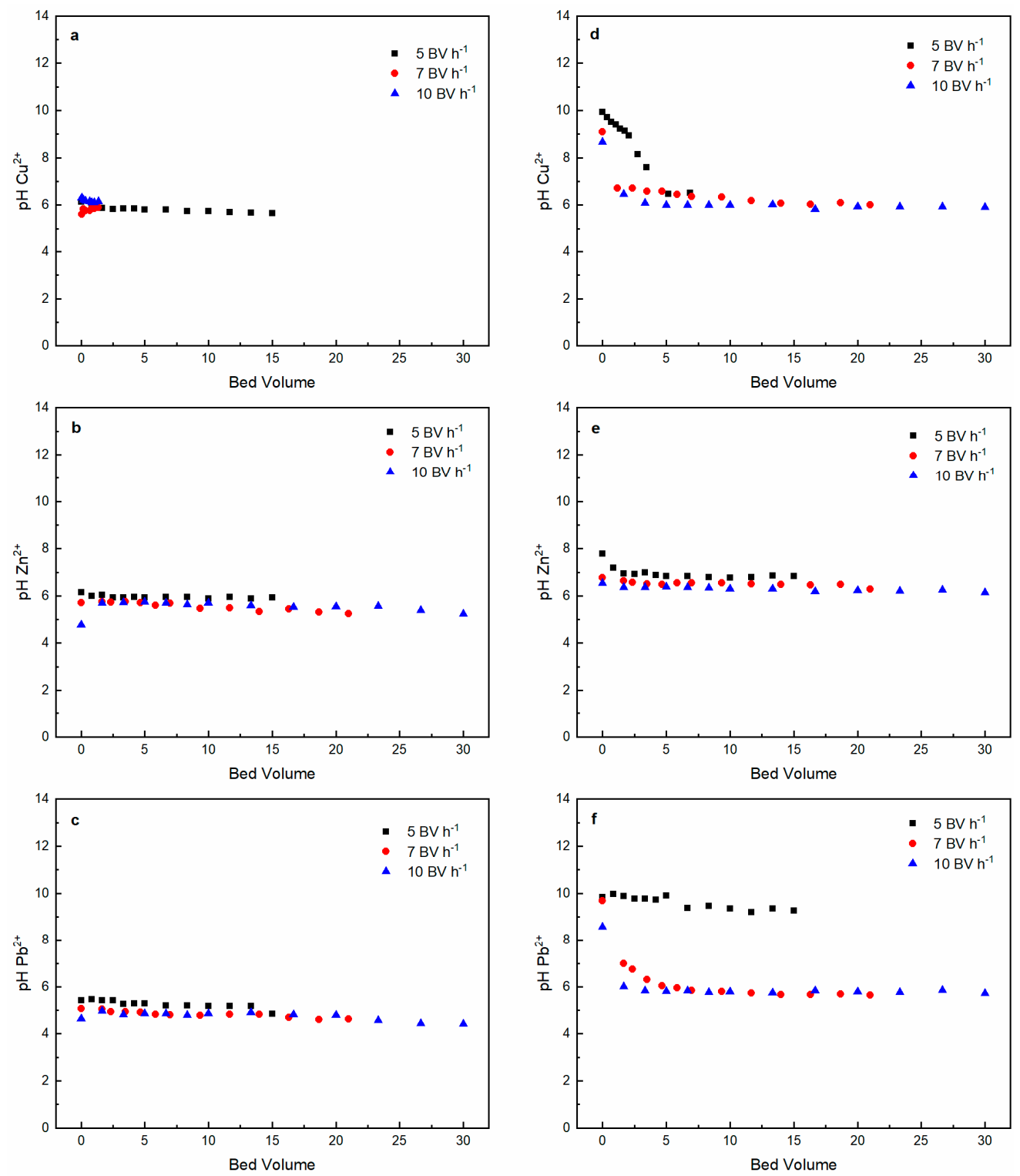

Figure 3. $\mathrm{pH}$ studies using clinoptilolite leaching $\mathrm{Cu}^{2+}(\mathbf{a}) ; \mathrm{Zn}^{2+}(\mathbf{b}) ; \mathrm{Pb}^{2+}(\mathbf{c})$ and zeolite A leaching $\mathrm{Cu}^{2+}(\mathbf{d}) ; \mathrm{Zn}^{2+}(\mathbf{e}) ; \mathrm{Pb}^{2+}(\mathbf{f})$.

As shown in Figure 4, the conductivity values decreased for all the experiments as a function of time, except for clinoptilolite leaching $\mathrm{Pb}^{2+}$. This indicates that the number of movable electrolyte ions in the solution decreased, which may be resulted from the adsorption mechanism. The existing ions in the bulk were adsorbed into the zeolite matrix, leading to a decrease in the conductivity of the effluent solution. It is worth noting that in the experiment of clinoptilolite leaching $\mathrm{Pb}^{2+}$, another removal behavior appeared. The conductivities in the effluent solutions nearly stayed at the same level around $400 \mu \mathrm{S}$ (the conductivity of raw solution was $404 \mu \mathrm{S}$ ), revealing that there might be only ion exchange in the removal process [38]. 

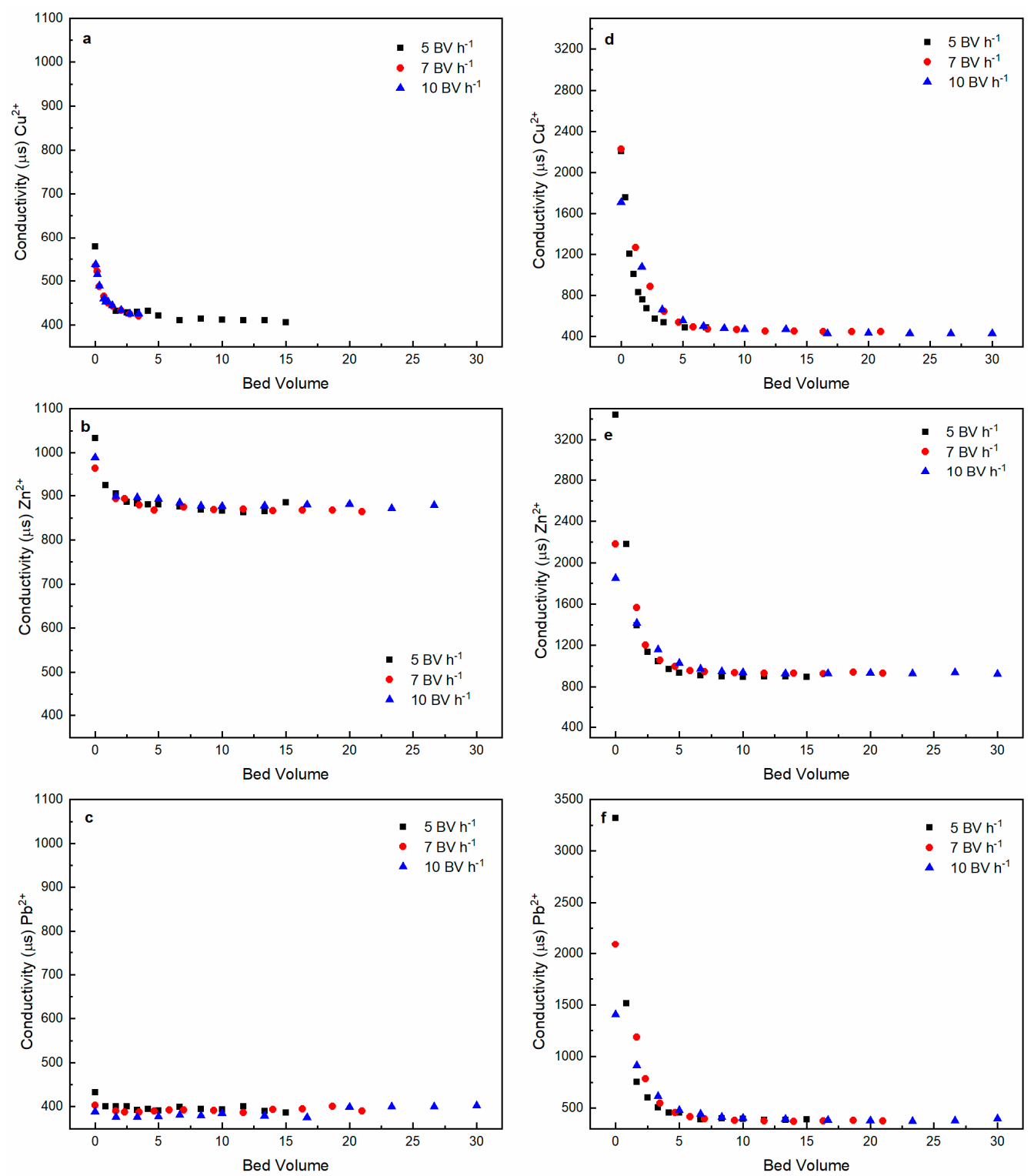

Figure 4. Conductivity studies of using clinoptilolite leaching $\mathrm{Cu}^{2+}(\mathbf{a}) ; \mathrm{Zn}^{2+}(\mathbf{b}) ; \mathrm{Pb}^{2+}(\mathbf{c})$ and zeolite A leaching $\mathrm{Cu}^{2+}(\mathbf{d}) ; \mathrm{Zn}^{2+}(\mathbf{e}) ; \mathrm{Pb}^{2+}(\mathbf{f})$.

As shown in Figure 5, at the end of experiments when using clinoptilolite, the removal percentage of $\mathrm{Pb}^{2+}$ was the most $(62.4 \%)$, followed by $\mathrm{Cu}^{2+}(32.7 \%)$, and the removed $\mathrm{Zn}^{2+}$ was the least $(21.55 \%)$. Under the same experimental conditions, zeolite A adsorbed the most amount of $\mathrm{Zn}^{2+}$ and the least $\mathrm{Pb}^{2+}$. This shows that the selectivity sequence among these three ions for clinoptilolite is: $\mathrm{Pb}^{2+}>\mathrm{Cu}^{2+}>\mathrm{Zn}^{2+}$, while it was $\mathrm{Zn}^{2+}>\mathrm{Cu}^{2+}>\mathrm{Pb}^{2+}$ for zeolite $\mathrm{A}$. In addition, the removal percentage for zeolite $\mathrm{A}$ towards $\mathrm{Pb}^{2+}$ is the least among all three ions, which can be explained by the Hard-Soft interaction theory: the harder the cations, the higher the charge density they have, and their d-orbitals do not participate in $\pi$-bond formation. This led to the higher possibility to conduct the electrostatic interaction $[46,47]$. However, as a soft cation, $\mathrm{Pb}^{2+}$ was least adsorbed by the zeolite A. 


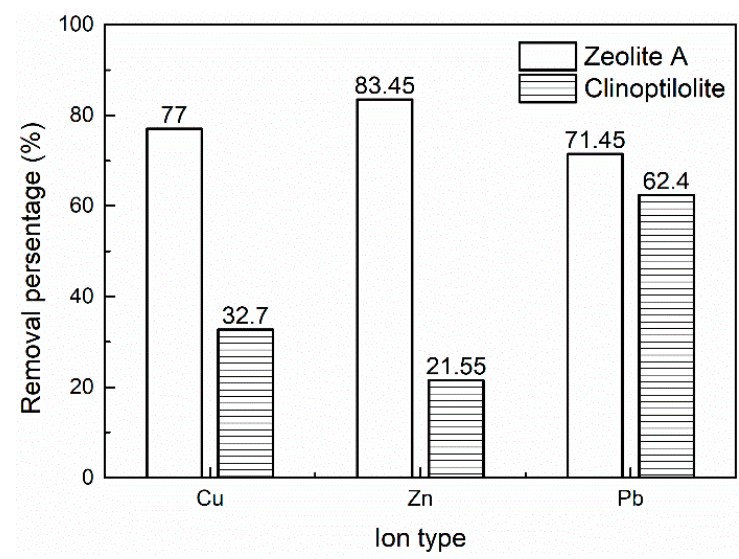

Figure 5. The removal percentages of clinoptilolite and zeolite A applied in different ions under $5 \mathrm{BV} \mathrm{h}^{-1}$ at the end of the experiment.

\subsection{Regeneration Experiments}

As can be seen from Figure 6a, the regenerated clinoptilolite followed a similar adsorption behavior with the clean clinoptilolite at the beginning of the experiment. However, as the adsorption proceeded, the regenerated clinoptilolites showed a weaker leaching ability than the pristine clinoptilolites. At the end of the adsorption, the removal percentage $\left(1-C_{t} / C_{0}\right) \times 100 \%$ dropped from $23.91 \%$ to $16.63 \%$ after the regeneration. This phenomenon also occurred frequently in other studies [12,48], illustrating two facts: 1 . The regeneration method was effective, which detached most of the $\mathrm{Zn}^{2+}$ ions that had been bound to the zeolite adsorption sites; 2 . Some of the residue $\mathrm{Zn}^{2+}$ ions were not completely removed from the zeolite matrix and still occupied part of the adsorption sites, resulting in a decrease in the removal percentage after regeneration.
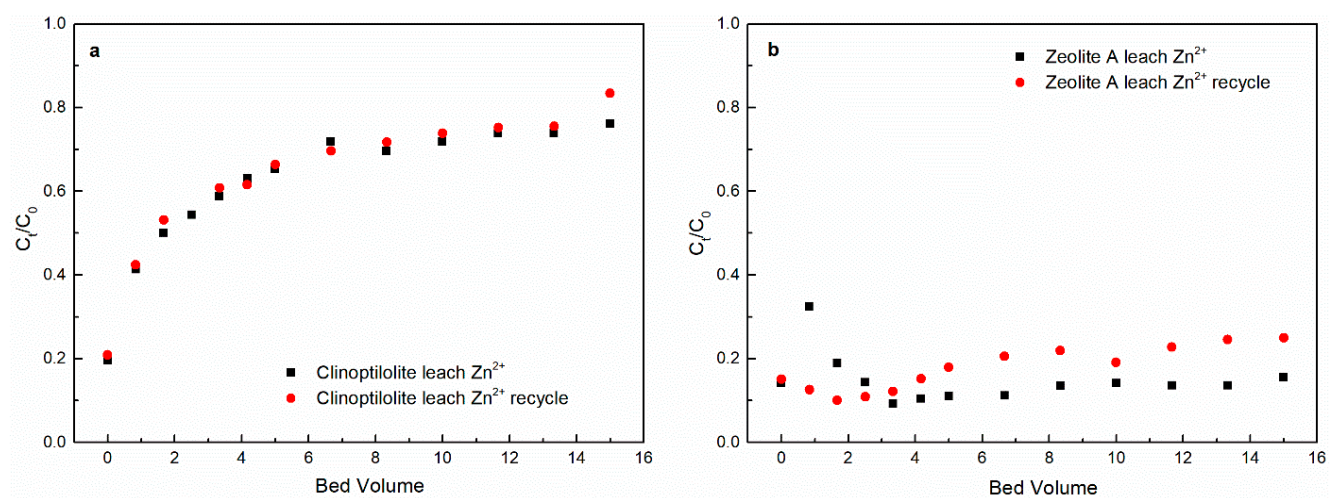

Figure 6. The breakthrough curves of the clinoptilolite (a) and zeolite A (b) leach $\mathrm{Zn}^{2+}$ under $5 \mathrm{BV} \mathrm{h}^{-1}$; the black data points represented pristine zeolites and the red data points stand for recycled zeolites.

The removal performance was represented by the removal percentage of $\mathrm{Zn}^{2+}$ ions in the solution at the end of the experiment. The corresponding removal percentages are listed in Table 1. Our findings suggest that the adsorption ability of each zeolite was similar after the regeneration, and the regeneration method to reactivate the used zeolite was effective. This work is a novel empirical example of the application of ultrasonication to treat contaminated zeolites. Our results encourage further research to investigate the processes and mechanisms using different classes of adsorbents and contaminants. 
Table 1. The removal performances of the clean zeolites used to remove the heavy metal ions for the first time (Original experiment) and the regenerated zeolites used to remove the heavy metal ions (Regeneration experiment).

\begin{tabular}{ccc}
\hline & & Removal Percentage (\%) \\
\hline \multirow{2}{*}{ Clinoptilolite leach $\mathrm{Zn}^{2+}$ at $5 \mathrm{BV} \mathrm{h}^{-1}$} & Original experiment & 23.91 \\
& Regeneration experiment & 16.63 \\
\hline \multirow{2}{*}{ Zeolite A leach $\mathrm{Zn}^{2+}$ at $5 \mathrm{BV} \mathrm{h}^{-1}$} & Original experiment & 84.44 \\
& Regeneration experiment & 74.99 \\
\hline
\end{tabular}

\subsection{Supportive Characterization of the Zeolites Associated with Heavy Metal Adsorption}

\subsubsection{SEM and EDX}

SEM-EDX analysis was conducted on clean and post-treatment samples of each zeolite. Clinoptilolite is a kind of material with a rough surface as shown in Figure 7a, and the ultrasonic bath did not change much on its morphology. As shown in Figure 7b, there are some plate-like coagulations on the surface. Additionally, smaller cubic-structured particles were formed on zeolite A after the adsorption process in Figure 7d, which indicates that there existed some substances on the surface after the adsorption of zinc ions.
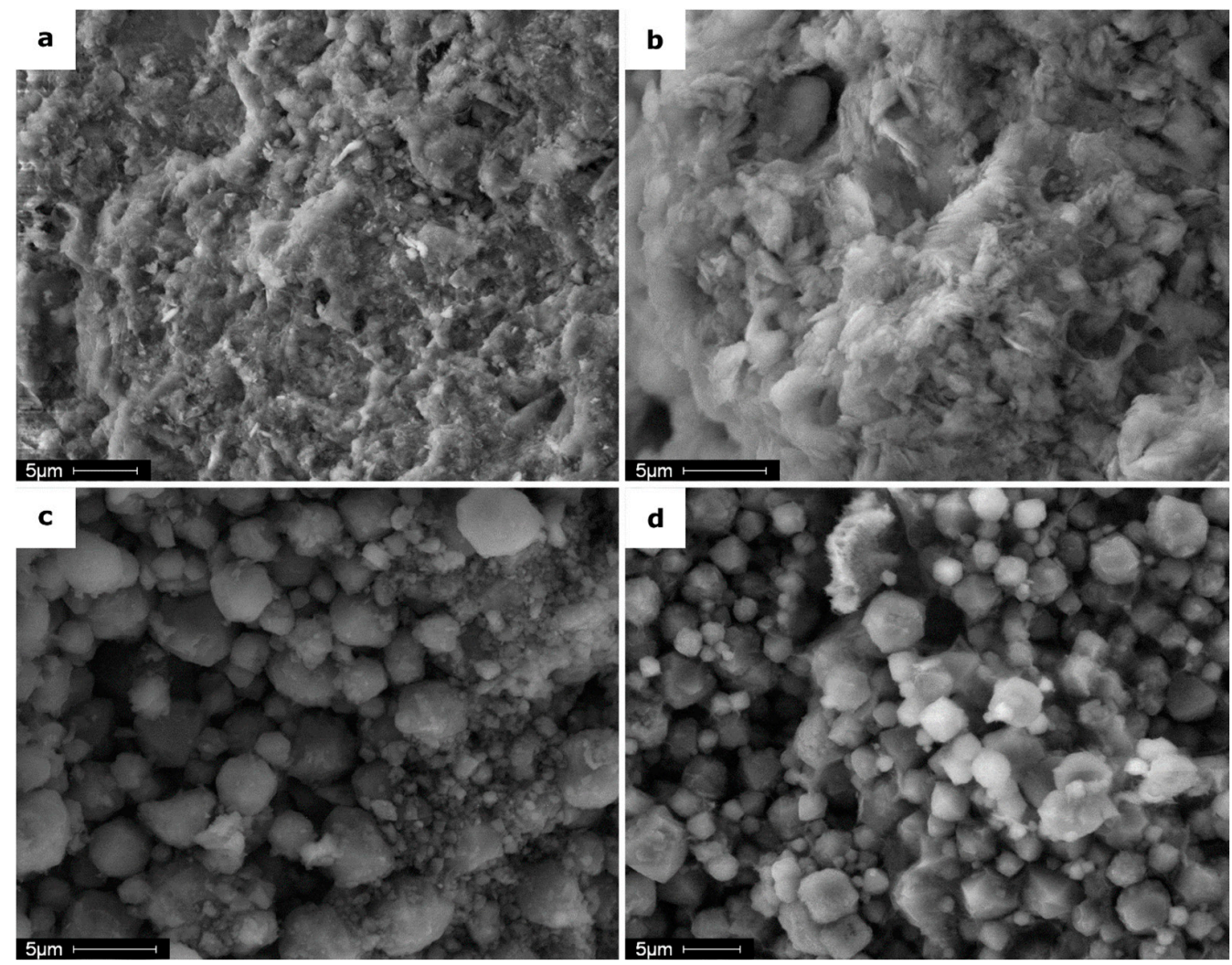

Figure 7. SEM results of clean clinoptilolite (a); $\mathrm{Zn}^{2+}$-contaminated clinoptilolite (b); clean zeolite A (c) and $\mathrm{Zn}^{2+}$-contaminated zeolite $\mathrm{A}(\mathbf{d})$.

In terms of the EDX analysis, the elements present in each zeolite sample and their atomic percentages were displayed in Table 2. Zinc was absent from the clean zeolites, and after the adsorption reaction, the zinc content increased to $1.33 \%$ for clinoptilolite, and it increased to $2.03 \%$ for zeolite A. These results directly proved that the adsorption was successful. Plus, the ratio of $\mathrm{Si} / \mathrm{Al}$ of clean clinoptilolite was around 4.14, which was similar to reported data 4.84 by Nezamzadeh-Ejhieh and Moeinirad $[49,50]$. 
Table 2. Elemental analysis of clean clinoptilolite, zinc-contaminated clinoptilolite, clean zeolite A and zinc-contaminated zeolite A.

\begin{tabular}{ccccccccc}
\hline Element Content (\%) & $\mathbf{S i}$ & $\mathbf{A l}$ & $\mathbf{K}$ & $\mathbf{N a}$ & $\mathbf{C a}$ & $\mathbf{M g}$ & $\mathbf{O}$ & $\mathbf{Z n}$ \\
\hline Clean clinoptilolite & 62.59 & 15.11 & 7.01 & 0 & 3.59 & 3.38 & 8.31 & 0 \\
$\mathrm{Zn}^{2+}$-contaminated & 61.69 & 12.26 & 5.31 & 0 & 5.21 & 2.65 & 11.55 & 1.33 \\
clinoptilolite & & & & & & & \\
Clean zeolite A & 46.97 & 25.57 & 3.88 & 5.43 & 2.12 & 3.7 & 12.33 & 0 \\
$\mathrm{Zn}^{2+}$-contaminated zeolite A & 45.53 & 24.77 & 3.27 & 6.17 & 3.05 & 3.49 & 11.69 & 2.03 \\
\hline
\end{tabular}

\subsubsection{BET}

The BET was also conducted for the aforementioned samples, and the results are shown in Table 3 below. After the adsorption, the surface area of clinoptilolite increased from $30.99 \mathrm{~m}^{2} \mathrm{~g}^{-1}$ to $44.17 \mathrm{~m}^{2} \mathrm{~g}^{-1}$. Similarly, the surface area of zeolite A drastically increased from $40.69 \mathrm{~m}^{2} \mathrm{~g}^{-1}$ to $301.48 \mathrm{~m}^{2} \mathrm{~g}^{-1}$, indicating that a more complex structure was formed.

Table 3. BET results of 4 samples (1: clean clinoptilolite; $2: \mathrm{Zn}^{2+}$-contaminated clinoptilolite; 3: clean zeolite A; 4: $\mathrm{Zn}^{2+}$-contaminated zeolite A).

\begin{tabular}{ccccc}
\hline & $\mathbf{1}$ & $\mathbf{2}$ & $\mathbf{3}$ & $\mathbf{4}$ \\
\hline BET surface area $\left(\mathrm{m}^{2} \mathrm{~g}^{-1}\right)$ & 30.99 & 44.17 & 40.69 & 301.48 \\
$\quad$ Micropore Volume & 0.17 & 0.31 & 1.07 & 1.40 \\
$\left(\times 10^{-2} \mathrm{~cm}^{3} \mathrm{~g}^{-1} \mathrm{STP}\right)$ & 2.74 & 5.23 & 18.68 & 244.28 \\
Micropore Area $\left(\mathrm{m}^{2} \mathrm{~g}^{-1}\right)$ & 28.26 & 38.95 & 22.01 & 57.20 \\
External Surface Area $\left(\mathrm{m}^{2} \mathrm{~g}^{-1}\right)$ & & &
\end{tabular}

\subsubsection{XRD}

The lattice parameters of the zeolites are also listed in the Table 4 below, where $\mathrm{a}, \mathrm{b}$ and $c$ represent the size of the unit cells, while $\alpha, \beta$ and $\gamma$ represent the angles of these unit cells. The tested samples include: 1 . clean clinoptilolite; $2 . \mathrm{Zn}^{2+}$-contaminated clinoptilolite; 3. clean zeolite $\mathrm{A} ; 4$. $\mathrm{Zn}^{2+}$-contaminated zeolite $\mathrm{A}$. Clinoptilolite unit cell has a wider $\beta$ angle, while the $\alpha$ and $\gamma$ angles are $90^{\circ}$. The heavy metal removal procedure reduced the overall size of the unit cell and transferred the lattice structure of clinoptilolite from the HEU phase-type to CHA phase-type. This phenomenon also happened to zeolite A. The lattice size of the zeolite A was decreased by half from that of the previous state. The detailed matching spectra was shown in the Supporting Information, where typical XRD peaks of $\mathrm{ZnO}$ were assigned at 31.84 (100), 34.51 (002), 47.63 (102), 56.71 (110), 62.69 (103), 69.18 (201) which agree with JCPDS PDF No. 88-0287 [51].

Table 4. The lattice parameters of zeolites before and after the adsorption of $\mathrm{Zn}^{2+}$.

\begin{tabular}{ccccc}
\hline & $\mathbf{1}$ & $\mathbf{2}$ & $\mathbf{3}$ & $\mathbf{4}$ \\
\hline Major Phase & $\begin{array}{c}\text { HEU } \\
\text { (Heulandite) }\end{array}$ & $\begin{array}{c}\text { CHA } \\
\text { (Chabazite) }\end{array}$ & $\begin{array}{c}\text { Sodium Aluminum } \\
\text { Silicate }\end{array}$ & $\begin{array}{c}\text { Sodium Zinc } \\
\text { Aluminum Silicate }\end{array}$ \\
\hline a $(\AA)$ & 17.536 & 8.845 & 24.9506 & 12.152 \\
b $(\AA)$ & 17.277 & 16.607 & 24.9506 & 12.152 \\
c $(\AA)$ & 7.409 & 9.746 & 24.9506 & 12.152 \\
$\alpha$ & $90^{\circ}$ & $90^{\circ}$ & $90^{\circ}$ & $90^{\circ}$ \\
$\beta$ & $116.62^{\circ}$ & $123.19^{\circ}$ & $90^{\circ}$ & $90^{\circ}$ \\
$\gamma$ & $90^{\circ}$ & $90^{\circ}$ & $90^{\circ}$ & $90^{\circ}$ \\
\hline
\end{tabular}

\subsection{Leaching Mechanism}

The charge deficit, which was resulted from the replacement of $\mathrm{Si}^{4+}$ by $\mathrm{Al}^{3+}$, enabled the tridymite structure to adsorb cations. Hence, both the adsorption and ion exchange 
happened simultaneously during the leaching process [52-54]. The leaching mechanisms can be summarized by the following equations:

$$
\begin{gathered}
\mathrm{nSi}-\mathrm{OH}+\mathrm{M}^{\mathrm{n}+} \leftrightarrow(\mathrm{Si}-\mathrm{O})_{\mathrm{n}}-\mathrm{M}+\mathrm{nH}^{+} \\
\mathrm{SiO}^{-}+\mathrm{MOH}^{+} \rightarrow \mathrm{SiOMOH} \\
\mathrm{nSiO}^{-}+\mathrm{M}^{\mathrm{n}+} \leftrightarrow(\mathrm{Si}-\mathrm{O})_{\mathrm{n}}-\mathrm{M} \\
\mathrm{nMOH}^{+}+\mathrm{M}^{\prime}(\mathrm{z}) \leftrightarrow \mathrm{M}_{\mathrm{n}}(\mathrm{z})+\mathrm{M}^{\prime \mathrm{n}+}+\mathrm{nOH}^{-}
\end{gathered}
$$

where $\mathrm{M}^{\mathrm{n}+}$ represents the heavy metal ions in the bulk solutions, while $\mathrm{M}^{\prime}(\mathrm{z})$ represents the free ions in the zeolites matrix. Among those equations, Equations (2)-(4) illustrate the adsorption process, while Equation (5) represents the ion exchange mechanism. A similar phenomenon was also found in using clinoptilolite-based electrodes for bromate determination. Electroactive cations in zeolite were exchanged by zeolitic compounds, hence the ion exchange was achieved through replacing the modifier agent to the cations of the supporting electrolyte in solution [55].

During the leaching process, more negatively charged surfaces became available, therefore leading to greater $\mathrm{Zn}^{2+}$ uptake [56]. According to the analysis of the characterization, the results of the experiments as well as the literature studies, the leaching procedure mainly consists of 3 steps. Take zeolite A leaching $\mathrm{Zn}^{2+}$ as an example; the details are shown in Figure 8.

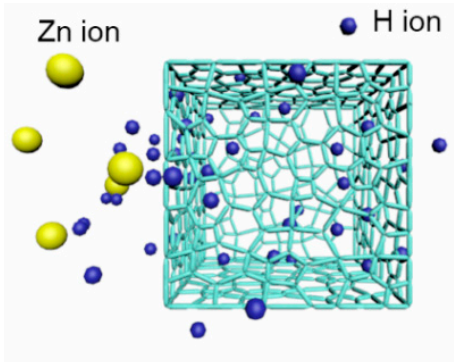

(a)

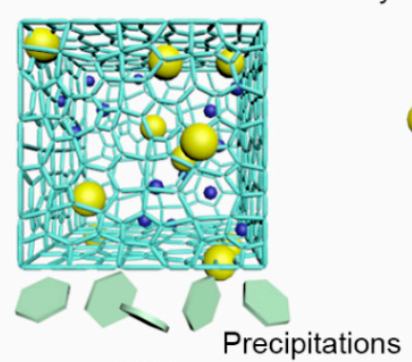

(b)

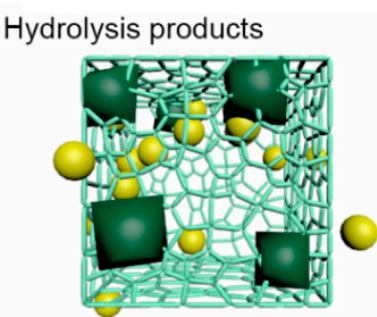

(c)

Figure 8. The leaching mechanism of the process: at the adsorption beginning stage: (a) The porous green cubic matrix of zeolite A were surrounded with yellow spheres $\mathrm{Zn}^{2+}$ ions, blue spheres the $\mathrm{H}^{+}$ ions. In the $\mathrm{pH}$ value elevation stage (b), the precipitates formed as green hexagonal plates. After the hydrolysis happened in stage (c), dark green cubic material was the hydrolysis complex formed at the surface of the pale blue matrix of the zeolite.

In Figure 8a, at the beginning of the adsorption, the $\mathrm{pH}$ of the bulk solution was 4 . According to the cation activity series, $\mathrm{H}^{+}$was also involved in the exchange process. At this time, monovalent $\mathrm{H}^{+}$entered the zeolite matrix and led to the rapid $\mathrm{pH}$ rise of the solution. Meanwhile, ions including $\mathrm{K}^{+}$and $\mathrm{Ca}^{2+}$ were also substituted, and therefore, a huge increase of conductivity from $915 \mu \mathrm{S}$ (raw $\mathrm{Zn}^{2+}$ solution conductivity) to around $3300 \mu \mathrm{S}$ under $5 \mathrm{BV} \mathrm{h}^{-1}$ was observed. As the $\mathrm{pH}$ was elevated in Figure $8 \mathrm{~b}$, more negatively charged surfaces become available, therefore leading to greater metal uptake, even at precipitation $\mathrm{pH}$ value [56]. This explained the remarkable leaching behavior of zeolites at the beginning of the experiments. During this stage, some ions were precipitated, while other partial ions entered the zeolite matrix. Both of the activities resulted in a dramatic drop in conductivity. As shown in Figure $8 \mathrm{c}$, after the $\mathrm{Zn}^{2+}$ ions entered the lattice structure, the hydrolysis began as:

$$
\left[\mathrm{M}\left(\mathrm{H}_{2} \mathrm{O}\right)_{\mathrm{x}}\right]^{\mathrm{c}+}+\mathrm{H}_{2} \mathrm{O} \leftrightarrow\left[\mathrm{M}\left(\mathrm{H}_{2} \mathrm{O}\right)^{\mathrm{x}-1}(\mathrm{OH})\right]^{(\mathrm{c}-1)+}+\mathrm{H}_{3} \mathrm{O}^{+}
$$

Zinc ions combined with water molecules created larger complexes and therefore produced $\mathrm{H}^{+}$. This process lowered the $\mathrm{pH}$ of the solution back to near neutral. This 
large complex gathered on the surface of the zeolite, increasing the specific surface area as shown in the BET results. Over time, the leaching process will reach saturation, that is, adsorbents will be exhausted. From then on, the conductivity in the solution will remain at a certain level.

\section{Conclusions}

In this work, the heavy metal ions leaching performances of natural clinoptilolite and synthesized zeolite A at different flow rates were comprehensively studied in a fixed-bed adsorption column. The removal preference of the two types of zeolites was found to be $\mathrm{Pb}^{2+}>\mathrm{Cu}^{2+}>\mathrm{Zn}^{2+}$ when using clinoptilolite, while it was $\mathrm{Zn}^{2+}>\mathrm{Cu}^{2+}>\mathrm{Pb}^{2+}$ for zeolite A. Among the two zeolites used for adsorption experiments, zeolite A is better for the adsorption of heavy metal ions in water than clinoptilolite. Namely, zeolite A leached 4 times higher $\mathrm{Zn}^{2+}$ ions under $5 \mathrm{BV} \mathrm{h}^{-1}$ in comparison to clinoptilolite $(83.45 \%$ for zeolite A and $21.55 \%$ for clinoptilolite). A novel regeneration method was applied by combining the ultrasonication and $\mathrm{NH}_{4} \mathrm{Cl}$ solution soaking. The regeneration method was effective without influencing the intrinsic zeolite properties. The unit cell stayed the same before and after the regeneration treatment, while the adsorption process created smaller secondary structures, especially on zeolite A. The surface area of zeolite A before adsorption was $40.69 \mathrm{~m}^{2} \mathrm{~g}^{-1}$ and it was $301.48 \mathrm{~m}^{2} \mathrm{~g}^{-1}$ after the adsorption. This was caused by the hydrolysis phenomenon. This study extends the use of zeolite beyond electrical-chemical wastewater treatment and agriculture: our results encourage testing the mentioned mechanisms when the novel regeneration method is applied.

Supplementary Materials: The following supporting information can be downloaded at: https: //www.mdpi.com/article/10.3390/en15010347/s1. Figure S1: XRD matching pattern of clean zeolite A; Figure S2: XRD matching pattern of clean clinoptilolite; Figure S3: XRD matching pattern of Zinc contami-nated zeolite A; Figure S4: XRD matching pattern of Zinc contaminated clinop-tilolite; Figure S5: BET results of clean zeolite A (a), $\mathrm{Cu}^{2+}$ contaminated zeolite A (b), clean clinoptilolite (c) and $\mathrm{Cu}^{2+}$ contaminated clinoptilolite $(\mathrm{d})$.

Author Contributions: Conceptualization, C.Y. and A.A.; methodology, C.Y.; software, C.Y.; validation, C.Y.; formal analysis, C.Y.; investigation, C.Y.; resources, A.A.; data curation, C.Y.; writing-original draft preparation, C.Y.; writing-review and editing, Y.W. and A.A.; visualization, C.Y.; supervision, Y.W. and A.A.; project administration, A.A.; funding acquisition, A.A. All authors have read and agreed to the published version of the manuscript.

Funding: This research received no external funding.

Institutional Review Board Statement: Not applicable.

Informed Consent Statement: Not applicable.

Data Availability Statement: The data presented in this study are available on request from the corresponding author.

Acknowledgments: The research reported in this publication was supported by the University of Manchester. The authors thank Desmond Doocey for his kind help with the ICP training.

Conflicts of Interest: The authors declare no conflict of interest.

\section{References}

1. Al-Juboori, O.; Sher, F.; Khalid, U.; Niazi, M.B.K.; Chen, G.Z. Electrochemical Production of Sustainable Hydrocarbon Fuels from $\mathrm{CO}_{2}$ Co-electrolysis in Eutectic Molten Melts. ACS Sustain. Chem. Eng. 2020, 8, 12877-12890. [CrossRef]

2. Al-Juboori, O.; Sher, F.; Hazafa, A.; Khan, M.K.; Chen, G.Z. The effect of variable operating parameters for hydrocarbon fuel formation from $\mathrm{CO}_{2}$ by molten salts electrolysis. J. CO2 Util. 2020, 40, 101193. [CrossRef]

3. Al-Shara, N.K.; Sher, F.; Yaqoob, A.; Chen, G.Z. Electrochemical investigation of novel reference electrode $\mathrm{Ni} / \mathrm{Ni}(\mathrm{OH})_{2}$ in comparison with silver and platinum inert quasi-reference electrodes for electrolysis in eutectic molten hydroxide. Int. J. Hydrogen Energy 2019, 44, 27224-27236. [CrossRef]

4. Al-Shara, N.K.; Sher, F.; Iqbal, S.Z.; Sajid, Z.; Chen, G.Z. Electrochemical study of different membrane materials for the fabrication of stable, reproducible and reusable reference electrode. J. Energy Chem. 2020, 49, 33-41. [CrossRef] 
5. Dunn, B.; Kamath, H.; Tarascon, J.-M.J.S. Electrical energy storage for the grid: A battery of choices. Science 2011, 334, $928-935$. [CrossRef] [PubMed]

6. Huang, J.; Guo, Z.; Ma, Y.; Bin, D.; Wang, Y.; Xia, Y. Recent Progress of Rechargeable Batteries Using Mild Aqueous Electrolytes. Small Methods 2019, 3, 1800272. [CrossRef]

7. $\quad$ Leong, K.W.; Wang, Y.; Ni, M.; Pan, W.; Luo, S.; Leung, D.Y.C. Rechargeable Zn-air batteries: Recent trends and future perspectives. Renew. Sustain. Energy Rev. 2022, 154, 111771. [CrossRef]

8. Heidari-Chaleshtori, M.; Nezamzadeh-Ejhieh, A. Clinoptilolite nano-particles modified with aspartic acid for removal of Cu(II) from aqueous solutions: Isotherms and kinetic aspects. New J. Chem. 2015, 39, 9396-9406. [CrossRef]

9. Enya, O.; Lin, C.; Qin, J. Heavy metal contamination status in soil-plant system in the Upper Mersey Estuarine Floodplain, Northwest England. Mar. Pollut. Bull. 2019, 146, 292-304. [CrossRef]

10. Tamiji, T.; Nezamzadeh-Ejhieh, A. A comprehensive study on the kinetic aspects and experimental design for the voltammetric response of a Sn(IV)-clinoptilolite carbon paste electrode towards Hg(II). J. Electroanal. Chem. 2018, 829, 95-105. [CrossRef]

11. Nosuhi, M.; Nezamzadeh-Ejhieh, A. Voltammetric determination of trace amounts of permanganate at a zeolite modified carbon paste electrode. New J. Chem. 2017, 41, 15508-15516. [CrossRef]

12. Luo, X.; Yuan, J.; Liu, Y.; Liu, C.; Zhu, X.; Dai, X.; Ma, Z.; Wang, F. Improved Solid-Phase Synthesis of Phosphorylated Cellulose Microsphere Adsorbents for Highly Effective $\mathrm{Pb}_{2}{ }^{+}$Removal from Water: Batch and Fixed-Bed Column Performance and Adsorption Mechanism. ACS Sustain. Chem. Eng. 2017, 5, 5108-5117. [CrossRef]

13. Shirzadi, H.; Nezamzadeh-Ejhieh, A. An efficient modified zeolite for simultaneous removal of $\mathrm{Pb}$ (II) and $\mathrm{Hg}$ (II) from aqueous solution. J. Mol. Liq. 2017, 230, 221-229. [CrossRef]

14. Fu, F.; Wang, Q. Removal of heavy metal ions from wastewaters: A review. J. Environ. Manag. 2011, 92, 407-418. [CrossRef]

15. Haddad, S.A.; Lemanowicz, J. Benefits of Corn-Cob Biochar to the Microbial and Enzymatic Activity of Soybean Plants Grown in Soils Contaminated with Heavy Metals. Energies 2021, 14, 5763. [CrossRef]

16. $\mathrm{Ku}, \mathrm{Y}$.; Jung, I.-L. Photocatalytic reduction of $\mathrm{Cr}(\mathrm{VI})$ in aqueous solutions by UV irradiation with the presence of titanium dioxide. Water Res. 2001, 35, 135-142. [CrossRef]

17. Vepsäläinen, M.; Sillanpää, M. Chapter 1-Electrocoagulation in the treatment of industrial waters and wastewaters. In Advanced Water Treatment; Sillanpää, M., Ed.; Elsevier: Amsterdam, The Netherlands, 2020; pp. 1-78.

18. Kurniawan, T.A.; Chan, G.Y.S.; Lo, W.-H.; Babel, S. Physico-chemical treatment techniques for wastewater laden with heavy metals. Chem. Eng. J. 2006, 118, 83-98. [CrossRef]

19. Pessoa, M.E.; de Sousa, K.S.; Clericuzi, G.Z.; Ferreira, A.L.; Soares, M.C.; Neto, J.C. Adsorption of Reactive Dye onto Uçá Crab Shell (Ucides cordatus): Scale-Up and Comparative Studies. Energies 2021, 14, 5876. [CrossRef]

20. Yang, C.; Wang, L.; Yu, Y.; Wu, P.; Wang, F.; Liu, S.; Luo, X. Highly efficient removal of amoxicillin from water by Mg-Al layered double hydroxide/cellulose nanocomposite beads synthesized through in-situ coprecipitation method. Int. J. Biol. Macromol. 2020, 149, 93-100. [CrossRef] [PubMed]

21. Burakov, A.E.; Galunin, E.V.; Burakova, I.V.; Kucherova, A.E.; Agarwal, S.; Tkachev, A.G.; Gupta, V.K. Adsorption of heavy metals on conventional and nanostructured materials for wastewater treatment purposes: A review. Ecotoxicol. Environ. Saf. 2018, 148, 702-712. [CrossRef] [PubMed]

22. Huang, H.; Li, J.-R.; Wang, K.; Han, T.; Tong, M.; Li, L.; Xie, Y.; Yang, Q.; Liu, D.; Zhong, C. An in situ self-assembly template strategy for the preparation of hierarchical-pore metal-organic frameworks. Nat. Commun. 2015, 6, 8847. [CrossRef]

23. Haw, J.F. Zeolite acid strength and reaction mechanisms in catalysis. Phys. Chem. Chem. Phys. 2002, 4, 5431-5441. [CrossRef]

24. Perić, J.; Trgo, M.; Vukojević Medvidović, N. Removal of zinc, copper and lead by natural zeolite-A comparison of adsorption isotherms. Water Res. 2004, 38, 1893-1899. [CrossRef]

25. Vaca Mier, M.; López Callejas, R.; Gehr, R.; Jiménez Cisneros, B.E.; Alvarez, P.J.J. Heavy metal removal with mexican clinoptilolite: Multi-component ionic exchange. Water Res. 2001, 35, 373-378. [CrossRef]

26. Alidusty, F.; Nezamzadeh-Ejhieh, A. Considerable decrease in overvoltage of electro-catalytic oxidation of methanol by modification of carbon paste electrode with Cobalt(II)-clinoptilolite nanoparticles. Int. J. Hydrogen Energy 2016, 41, 6288-6299. [CrossRef]

27. Nosuhi, M.; Nezamzadeh-Ejhieh, A. High catalytic activity of Fe(II)-clinoptilolite nanoparticales for indirect voltammetric determination of dichromate: Experimental design by response surface methodology (RSM). Electrochim. Acta 2017, 223, 47-62 [CrossRef]

28. Wang, S.; Peng, Y. Natural zeolites as effective adsorbents in water and wastewater treatment. Chem. Eng. J. 2010, 156, 11-24. [CrossRef]

29. Zanin, E.; Scapinello, J.; de Oliveira, M.; Rambo, C.L.; Franscescon, F.; Freitas, L.; de Mello, J.M.M.; Fiori, M.A.; Oliveira, J.V.; Dal Magro, J. Adsorption of heavy metals from wastewater graphic industry using clinoptilolite zeolite as adsorbent. Process Saf. Environ. Prot. 2017, 105, 194-200. [CrossRef]

30. Kocasoy, G.; Şahin, V. Heavy metal removal from industrial wastewater by clinoptilolite. J. Environ. Sci. Health Part A 2007, 42, 2139-2146. [CrossRef] [PubMed]

31. Çoruh, S. The removal of zinc ions by natural and conditioned clinoptilolites. Desalination 2008, 225, 41-57. [CrossRef]

32. Nezamzadeh-Ejhieh, A.; Banan, Z. A comparison between the efficiency of CdS nanoparticles/zeolite A and CdO/zeolite A as catalysts in photodecolorization of crystal violet. Desalination 2011, 279, 146-151. [CrossRef] 
33. Nezamzadeh-Ejhieh, A.; Mirzaeyan, E. Hexadecylpyridinium surfactant modified zeolite A as an active component of a polymeric membrane sulfite selective electrode. Mater. Sci. Eng. C 2013, 33, 4751-4758. [CrossRef]

34. Fareed, B.; Sher, F.; Sehar, S.; Rasheed, T.; Zafar, F.; Ameen, M.; Lima, E.C. Tailor made Functional Zeolite as Sustainable Potential Candidates for Catalytic Cracking of Heavy Hydrocarbons. Catal. Lett. 2021, 1-13. [CrossRef]

35. Turan, M.; Mart, U.; Yüksel, B.; Çelik, M.S. Lead removal in fixed-bed columns by zeolite and sepiolite. Chemosphere 2005, 60, 1487-1492. [CrossRef]

36. Netzer, A.; Hughes, D.E. Adsorption of copper, lead and cobalt by activated carbon. Water Res. 1984, 18, 927-933. [CrossRef]

37. Arulanantham, A.; Balasubramanian, N.; Ramakrishna, T.V. Coconut shell carbon for treatment of cadmium and lead containing wastewater. Met. Finish. 1989, 87, 51-55.

38. Stylianou, M.A.; Hadjiconstantinou, M.P.; Inglezakis, V.J.; Moustakas, K.G.; Loizidou, M.D. Use of natural clinoptilolite for the removal of lead, copper and zinc in fixed bed column. J. Hazard. Mater. 2007, 143, 575-581. [CrossRef]

39. Demirel, S.; Uyanik, I. Simultaneous fluoride and nitrate removal from drinking water using mixotrophic denitrification processes in a fixed bed column reactor. Desalination Water Treat. 2019, 164, 56-61. [CrossRef]

40. Liu, H.; Peng, S.; Shu, L.; Chen, T.; Bao, T.; Frost, R.L. Magnetic zeolite NaA: Synthesis, characterization based on metakaolin and its application for the removal of $\mathrm{Cu}_{2}{ }^{+}, \mathrm{Pb}_{2}{ }^{+}$. Chemosphere 2013, 91, 1539-1546. [CrossRef]

41. Wieland, E.; Stumm, W. Dissolution kinetics of kaolinite in acidic aqueous solutions at $25^{\circ} \mathrm{C}$. Geochim. Cosmochim. Acta 1992, 56, 3339-3355. [CrossRef]

42. Ames, L.L., Jr. Cation sieve properties of the open zeolites chabazite, mordenite, erionite and clinoptilolite. Am. Mineral. 1961, 46, $1120-1131$.

43. Neveu, A.; Gaspard, M.; Blanchard, G.; Martin, G. La diffusion intraparticulaire dans la clinoptilolite application aux ions $\mathrm{Na}^{+}$et $\mathrm{NH}_{4}{ }^{+}$. Water Res. 1985, 19, 611-618. [CrossRef]

44. Kurtoğlu, A.E.; Atun, G. Determination of kinetics and equilibrium of Pb/Na exchange on clinoptilolite. Sep. Purif. Technol. 2006, 50, 62-70. [CrossRef]

45. Inglezakis, V.J.; Stylianou, M.A.; Gkantzou, D.; Loizidou, M.D. Removal of $\mathrm{Pb}$ (II) from aqueous solutions by using clinoptilolite and bentonite as adsorbents. Desalination 2007, 210, 248-256. [CrossRef]

46. Mehrali-Afjani, M.; Nezamzadeh-Ejhieh, A. Efficient solid amino acid-clinoptilolite nanoparticles adsorbent for Mn(II) removal: A comprehensive study on designing the experiments, thermodynamic and kinetic aspects. Solid State Sci. 2020, 101, 106124. [CrossRef]

47. Nezamzadeh-Ejhieh, A.; Afshari, E. Modification of a PVC-membrane electrode by surfactant modified clinoptilolite zeolite towards potentiometric determination of sulfide. Microporous Mesoporous Mater. 2012, 153, 267-274. [CrossRef]

48. Luo, X.; Lei, X.; Cai, N.; Xie, X.; Xue, Y.; Yu, F. Removal of Heavy Metal Ions from Water by Magnetic Cellulose-Based Beads with Embedded Chemically Modified Magnetite Nanoparticles and Activated Carbon. ACS Sustain. Chem. Eng. 2016, 4, 3960-3969. [CrossRef]

49. Nezamzadeh-Ejhieh, A.; Moeinirad, S. Heterogeneous photocatalytic degradation of furfural using NiS-clinoptilolite zeolite. Desalination 2011, 273, 248-257. [CrossRef]

50. Nezamzadeh-Ejhieh, A.; Shirvani, K. CdS loaded an Iranian clinoptilolite as a heterogeneous catalyst in photodegradation of p-aminophenol. J. Chem. 2013, 2013, 541736. [CrossRef]

51. Derikvandi, H.; Nezamzadeh-Ejhieh, A. Increased photocatalytic activity of $\mathrm{NiO}$ and ZnO in photodegradation of a model drug aqueous solution: Effect of coupling, supporting, particles size and calcination temperature. J. Hazard. Mater. 2017, 321, 629-638 [CrossRef]

52. Busca, G. Acidity and basicity of zeolites: A fundamental approach. Microporous Mesoporous Mater. 2017, 254, 3-16. [CrossRef]

53. Keane, M.A. The removal of copper and nickel from aqueous solution using Y zeolite ion exchangers. Colloids Surf. A Physicochem. Eng. Asp. 1998, 138, 11-20. [CrossRef]

54. Cabrera, C.; Gabaldón, C.; Marzal, P. Sorption characteristics of heavy metal ions by a natural zeolite. J. Chem. Technol. Biotechnol. 2005, 80, 477-481. [CrossRef]

55. Tamiji, T.; Nezamzadeh-Ejhieh, A. Sensitive voltammetric determination of bromate by using ion-exchange property of a Sn(II)-clinoptilolite-modified carbon paste electrode. J. Solid State Electrochem. 2019, 23, 143-157. [CrossRef]

56. Ijagbemi, C.O.; Baek, M.H.; Kim, D.S. Montmorillonite surface properties and sorption characteristics for heavy metal removal from aqueous solutions. J. Hazard. Mater. 2009, 166, 538-546. [CrossRef] [PubMed] 